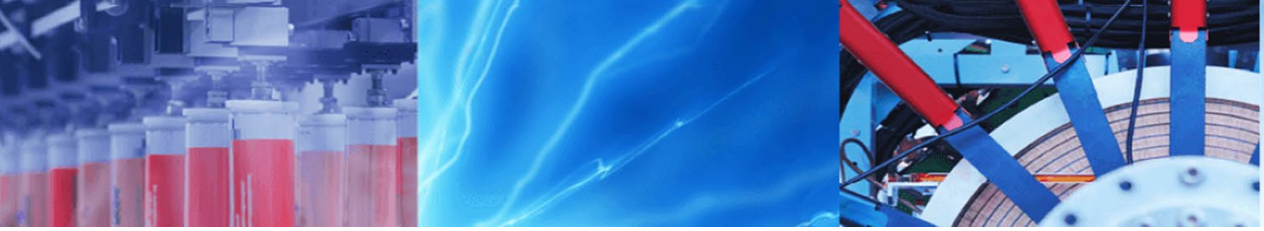

Research Article

\title{
Agro-climatic zone-based identification of elite Terminalia arjuna accessions concerning to arjunolic acid production
}

\author{
Sonu Bharti ${ }^{1,2}$
}

Received: 16 July 2020 / Accepted: 12 January 2021 / Published online: 1 February 2021

(c) The Author(s) 2021 OPEN

\begin{abstract}
Man has been dependent on vegetation in different forms since antiquity. Plants and trees have been used in the form of medications since the old times. Although the use of plant parts in the form of medicine has been less than that of the plants, therefore today it is necessary to explore some such medicinal trees. Among these, one of these trees is Arjun, whose bark is described also in Ayurveda due to its divine medicinal properties in heart diseases. The present study based on the isolation and analysis of the Phyto-constituents of the stem bark extract of Terminalia arjuna member to the family Combretaceae collected from different agro-climatic zones of India. The samples were subjected to quantitative phytochemical analysis i.e., arjunolic acid, screening by implementing the standard procedure. Observation has shown the presence of arjunolic acid in the stem bark extracts in different fractions obtained by the use of various organic solvents. Therefore, the bark extracts of the chosen plants may function as a good source of components of useful drugs for cardiovascular disorders and may also be used for the preparation of other pharmaceutical products.
\end{abstract}

Keywords Arjunolic acid · Combretaceae · HPTLC · Agroclimatic zone

\section{Introduction}

Men have been using plant-based medicines since time immemorial. Almost every civilization has a history of using medicinal plants. According to Ncube et al. [1], Medicinal plants are the prerequisite for the traditional systems of medicines, pharmaceutical industries for synthetic drugs. In ancient times, Egyptians, Indians, Chinese, Africans and others used a variety of plant products for curing all kinds of ailments [2]. The hypocholsteremic, hypolipidemic, anticoagulant, antihypertensive, antithrombotic, antiviral, antifungal and antibacterial activities of arjunolic acid were seen by the Tripathi and Singh [3] and Pettit et al. [4] in their findings. The effectiveness of arjunolic acid in many cardiac disorders like angina, myocardial infraction, hypertension, hypercholesteremia, cardiac arrest etc. were reported by the Rose and Treadway [5] and Khan and Balick [6]. Other studies also reported that it's bark retains significant hypotensive effect, increasing coronary artery flow and protecting myocardium against ischemic damage and mild diuretic, antithrombotic, prostaglandin E (2) enhancing and hypolipidemic activity of arjunolic acid the experimental findings by the Dwivedi [7].

Thus, medicinal plants are the local heritage with global importance. The number of flowering plants on the earth estimated presently is about $2,50,000$ species of which nearly 70,000 species are used for medicinal purposes, both in developed and developing countries [8]. An estimate suggests that about 13,000 plant species are known to have worldwide use as drugs.

It is reported that $41 \%$ prescription in the USA and $50 \%$ in Europe contains constituents from natural products.

$\triangle$ Sonu Bharti, sonugpb@rediffmail.com $\mid{ }^{1}$ Genetics and Plant Propagation Division, Tropical Forest Research Institute, Jabalpur, Madhya Pradesh 482021, India. ${ }^{2}$ Present Address: Department of Life Science, National Institute of Technology Rourkela, Odisha 769008, India. 
Phytochemical tests have been performed on about 5000 species; and nearly 1100 species are extensively exploited in $80 \%$ of Ayurvedic, $46 \%$ of Unani and $33 \%$ of Allopathic medicines [9]. India has $2.4 \%$ of the world's land area with $8 \%$ of global biodiversity and harbors one of the 12-mega diversity centers, having over 45,000 plant species. Its diversity is unmatched due to the presence of 16 different agro-climatic zones, 10 vegetative zones and 15 biotic provinces [10]. The country accounts for 17,500 species of higher plants. Of these, more than 2000 documented species exhibit medicinal value vis-à-vis 1100 species being used in different systems of medicines.

International trade in medicinal plants and phytopharmaceutical preparations is a major force in the world economy. Their demands are increasing both in developing and industrialized nations. A report prepared by the Export-Import Bank of India has estimated that the international market of medicinal plant-related products is in the range of US\$ 107 billion with an annual growth rate of $7 \%$ (According to Global Summit on Herbals \& Natural Remedies, Chicago, USA). According to research from global Industry Analysis, the global herbal supplement and remedy industry has been estimated to be $\$ 107$ billion by 2017. India's share in the global herbal market in the year 2017 is of the order of 2 billion dollars. India is the second-largest exporter, next to China. According to the current estimation, phytomedicines used in health care globally by $40 \%$ of the total population [11].

A different system of treatments such as ayurvedic, Unani, homeopathy and siddha originated in India. India is the birth-place of the renewed system of indigenous medicine such as Unani, Ayurveda, Homeopathy and Siddha. In India, nearly $95 \%$ of the prescriptions were planted primarily based on ancient systems [12]. In this study, the quantitative estimation of Phyto-constituents of stem bark of Terminalia arjuna commonly referred to as "Arjun" (fam-Combretaceae), was done for the presence of arjunolic acid.

The study was conducted to assess the natural variation of Terminalia arjuna to investigate the populations along with the natural habitats of this medicinal plant for the phytochemical contents upon comparison from nine states and five different agro-climatic zones of India. The main scope of this experiment was the selection of the Terminalia arjuna accessions with a high content of arjunolic acid from the various population collected from different agro-climatic zones.

\section{Materials and methods}

\subsection{Collection and processing of plant samples}

Plant samples (mapping population) of Terminalia arjuna were obtained from All India germplasm of arjun established between 2001 and 2004 at Central Tasar Research and Training Institute (CTRTI), Nagri, Ranchi that maintains superior arjun accessions from nine states, viz., Andhra Pradesh, Assam, Chhattisgarh, Jharkhand, Maharashtra, Madhya Pradesh, Orissa, Uttrakhand and Uttar Pradesh altogether representing five agro-climatic zones, viz., Eastern plateau and hill (EPH) regions, Southern plateau and hills (SPH) region, Eastern Himalayan (EH) Region, Western Himalayan (WH) region and Central plateau and hills $(\mathrm{CPH})$ region (Fig. 1). For the selection of various accessions of Terminalia arjuna tress, some criteria were chosen: the tress growth should be vigorous, healthy and showing superiority in height and diameter i.e., straight, cylindrical, non-forking, non-twisting bole when compared with surrounding trees and resistant to pests and diseases. The distance between the collections of two accessions must be at least $200 \mathrm{~m}$ from their natural habitat. A total of 140 accessions were sampled for bark patch $(10 \mathrm{~cm} \times 10 \mathrm{~cm})$ at $1.34 \mathrm{~m}$ diameter breast height $(\mathrm{DBH})$ for the estimation of arjunolic acid content. The details of the accessions of arjun represent different agro-climatic regions bark are given in Table 1.

\subsection{Chemicals}

Only HPLC and/or analytical grade chemicals and reagents (Sigma, USA; Himedia, USA; Merck, Germany, etc.) were used during the present study.

\subsection{Collection and processing of bark patch}

A bark patch of $10 \mathrm{~cm} \times 10 \mathrm{~cm}$ was sustainably removed at $1.34 \mathrm{~m}$ from each of 140 accessions of Terminalia arjuna. The thickness of the sampled bark patch was measured at several places by Vernier calliper. The bark was washed with distilled water, followed by the estimation of its fresh weight. Subsequently, the bark patch was shrouded and cut into the pieces and dried at room temperature in the shade and watched regularly to reduce the attack of fungi. It took a week or so until attaining a constant dry weight that measured and recorded. A fine powder of dried bark patches was made with the help of grinder and sieved through a $25 \mathrm{~mm}$ fine mesh and divided into three parts representing as replicates for 


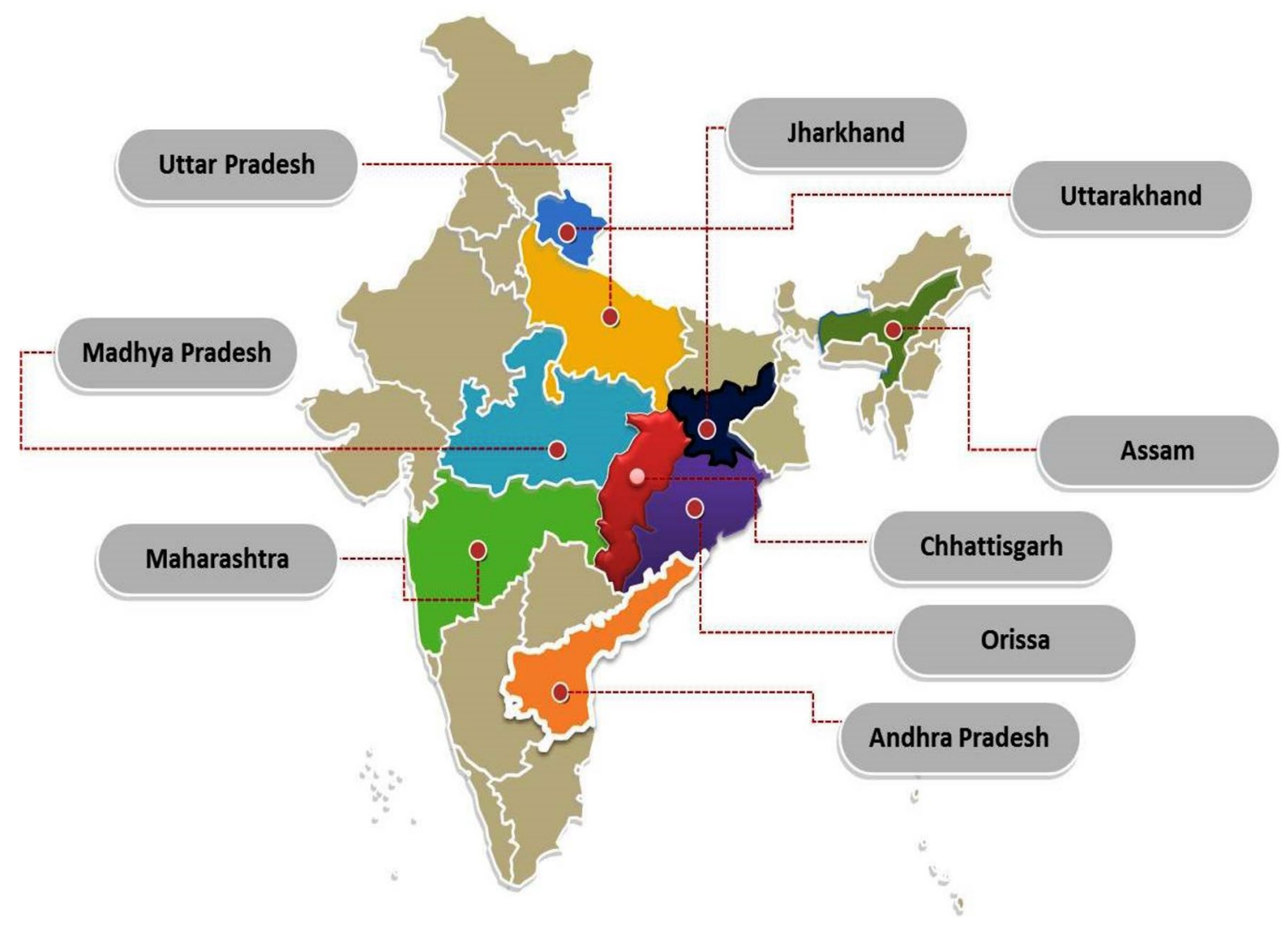

Fig. 1 Map showing the state-wise location of the sampled mapping population

extraction and estimation of arjunolic acid and stored in air-tight containers with necessary markings for identification and kept in a cool, dark and dry place for further use.

\subsubsection{Extraction of arjunolic acid from bark powder}

$200 \mathrm{mg}$ bark powder was exactly weighed and placed in a conical flask $(100 \mathrm{ml})$ and then mixed with $20 \mathrm{ml}$ of ethyl acetate. All conical flasks were retained for $10 \mathrm{~min}$ for presoaking as pre-leaching. It was followed by an extraction process that was performed by warming the content at $65^{\circ} \mathrm{C}$ for five $\mathrm{min}$, i.e. below boiling point $\left(71.1^{\circ} \mathrm{C}\right)$ of the ethyl acetate in a $600 \mathrm{~W}$ microwave oven. An irradiation treatment was given to the samples under microwave for one minute followed by cooling for $1 \mathrm{~min}$ between two irradiations. Whatman filter paper no. 1 was used for the filtration of suspensions. The residue was washed twice with ethyl acetate. The washings were pooled with the filtrate and the solvent was vacuum evaporated at $40^{\circ} \mathrm{C}$ (Vacuum Oven, TEMPO Instruments Pvt. Ltd) and lyophilized. The solvent-free residue was dissolved in $1 \mathrm{ml} \mathrm{HPLC}$ grade methanol and transferred to $1.5 \mathrm{ml}$ Eppendorf tubes and stored at $-20^{\circ} \mathrm{C}$ in the deep freezer until estimation of arjunolic acid on HPTLC.

\subsection{Arjunolic acid standard}

A pure sample of arjunolic acid (MW 488.70, Melting point $296^{\circ} \mathrm{C}$, purity $>99 \%$ ) as one mg powder (vial) was purchased from Sigma-Aldrich India, was used in the concentration $1000 \mu \mathrm{g} / \mathrm{ml}$. The working standard solution of $100 \mu \mathrm{g} / \mathrm{ml}$ was prepared from the standard stock solution by drawing a known volume of the latter and diluting in the ratio of 1:10 by HPLC grade methanol. A volume of the working standard (arjunolic acid) solution equal to that of the bark sample was loaded alongside the latter on the HPTLC plate. The peak area of the standard arjunolic acid was used for the computation of arjunolic acid in the bark sample extract.

\subsection{HPTLC processing and estimation of arjunolic acid in the bark extract}

HPTLC processing needs a clean pre-coated and activated silica aluminum plate, a micro-syringe (dispenser) for loading standard solution/ sample extract, oven, twin trough 


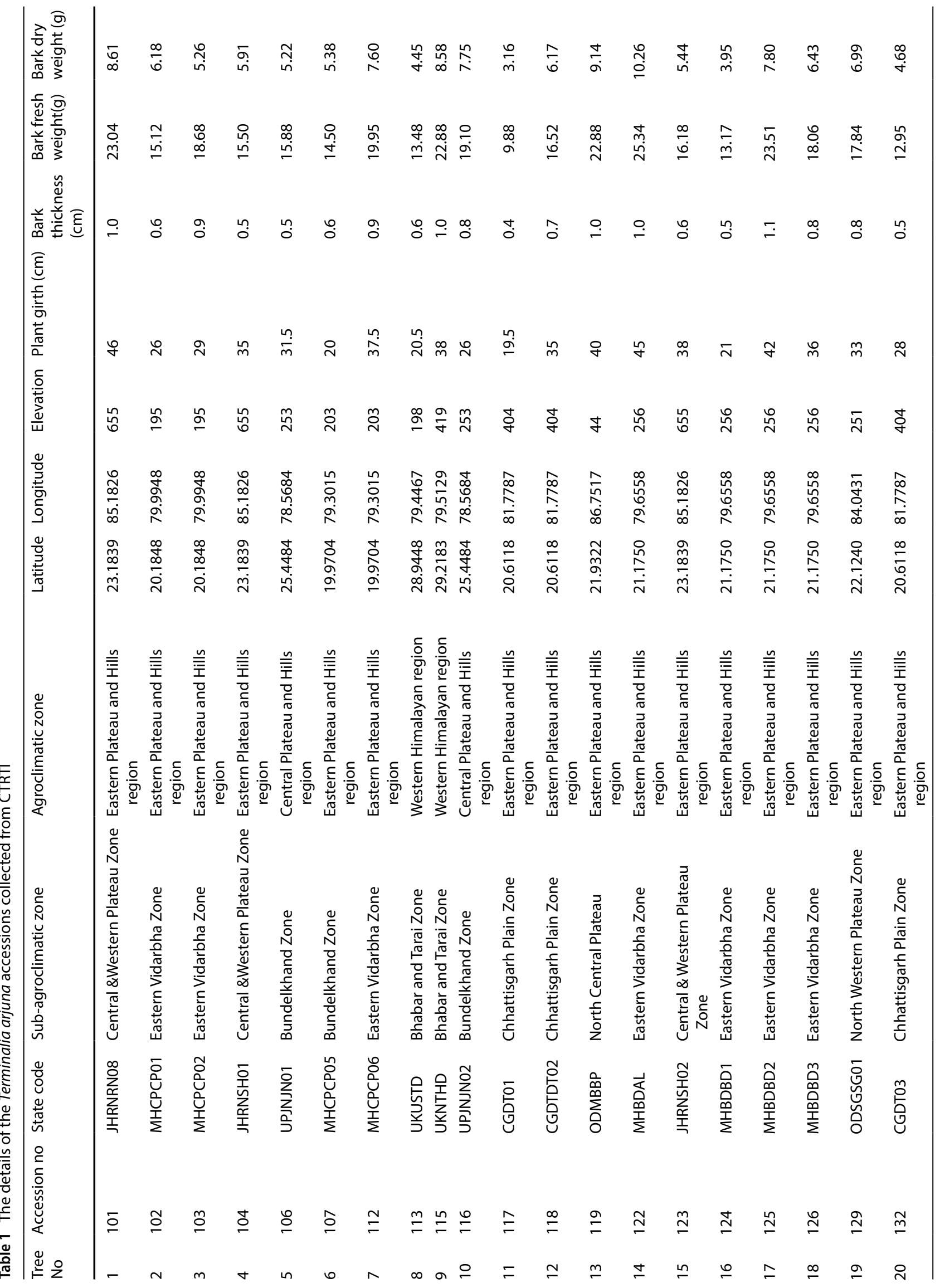




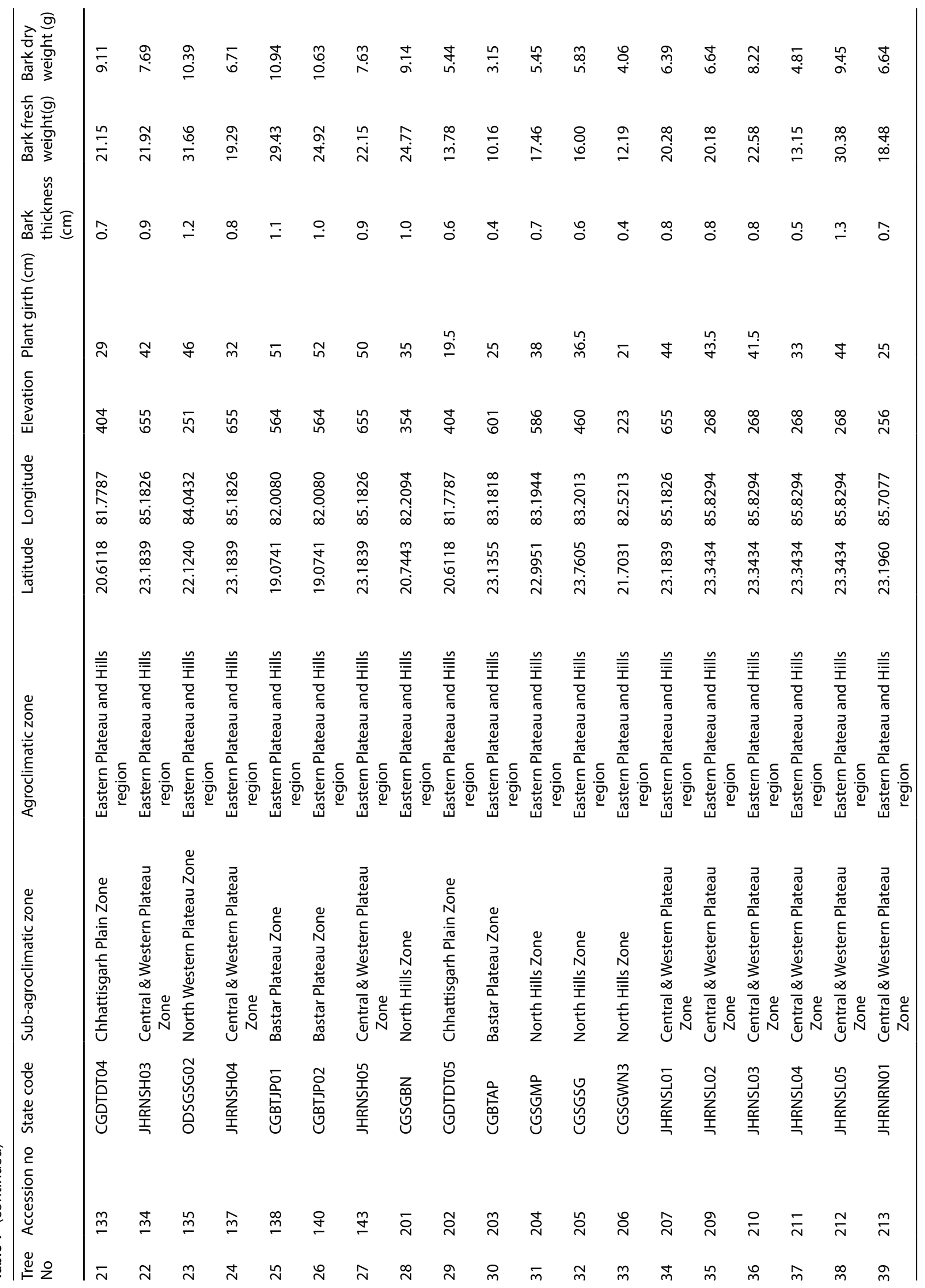




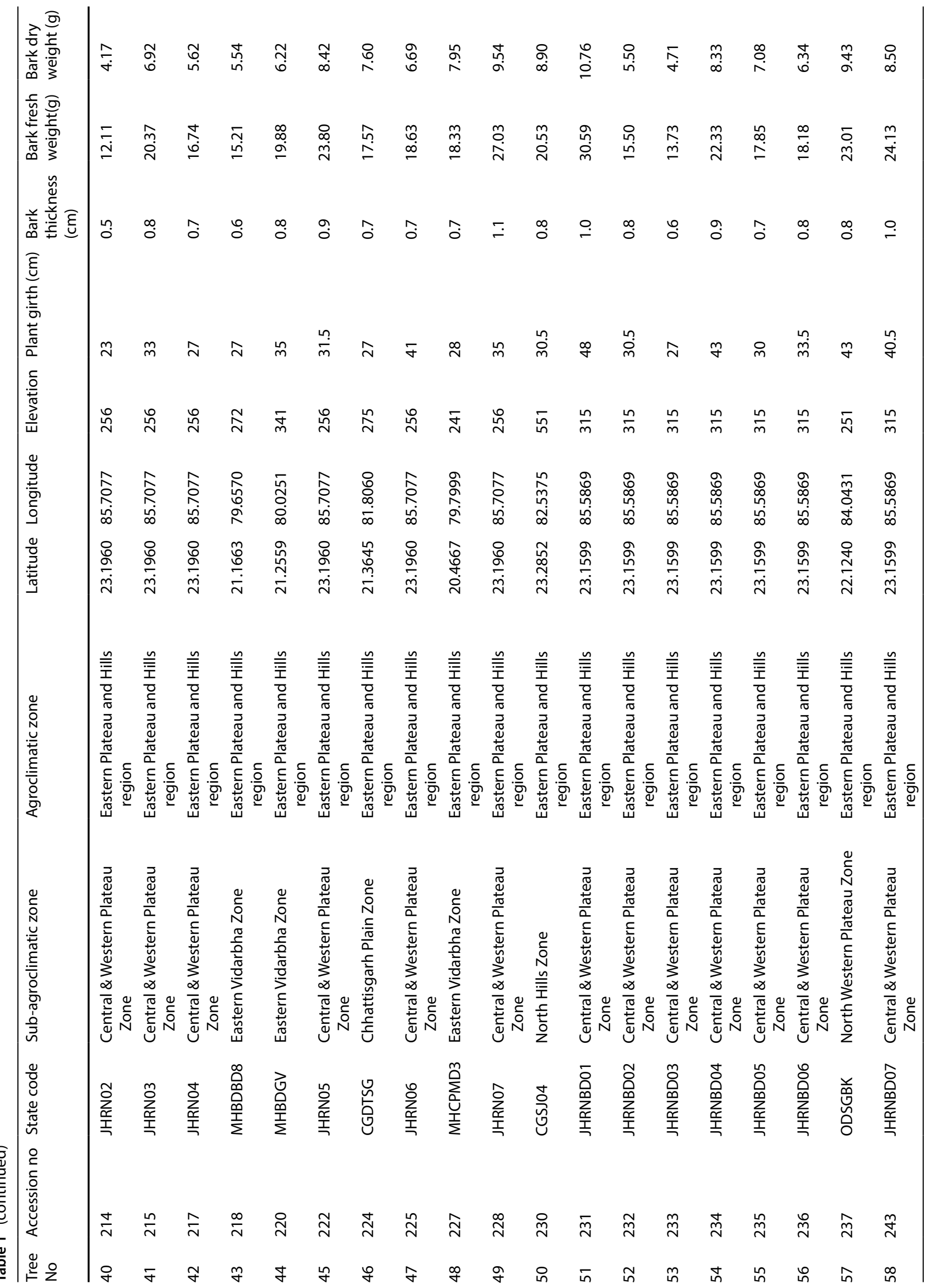




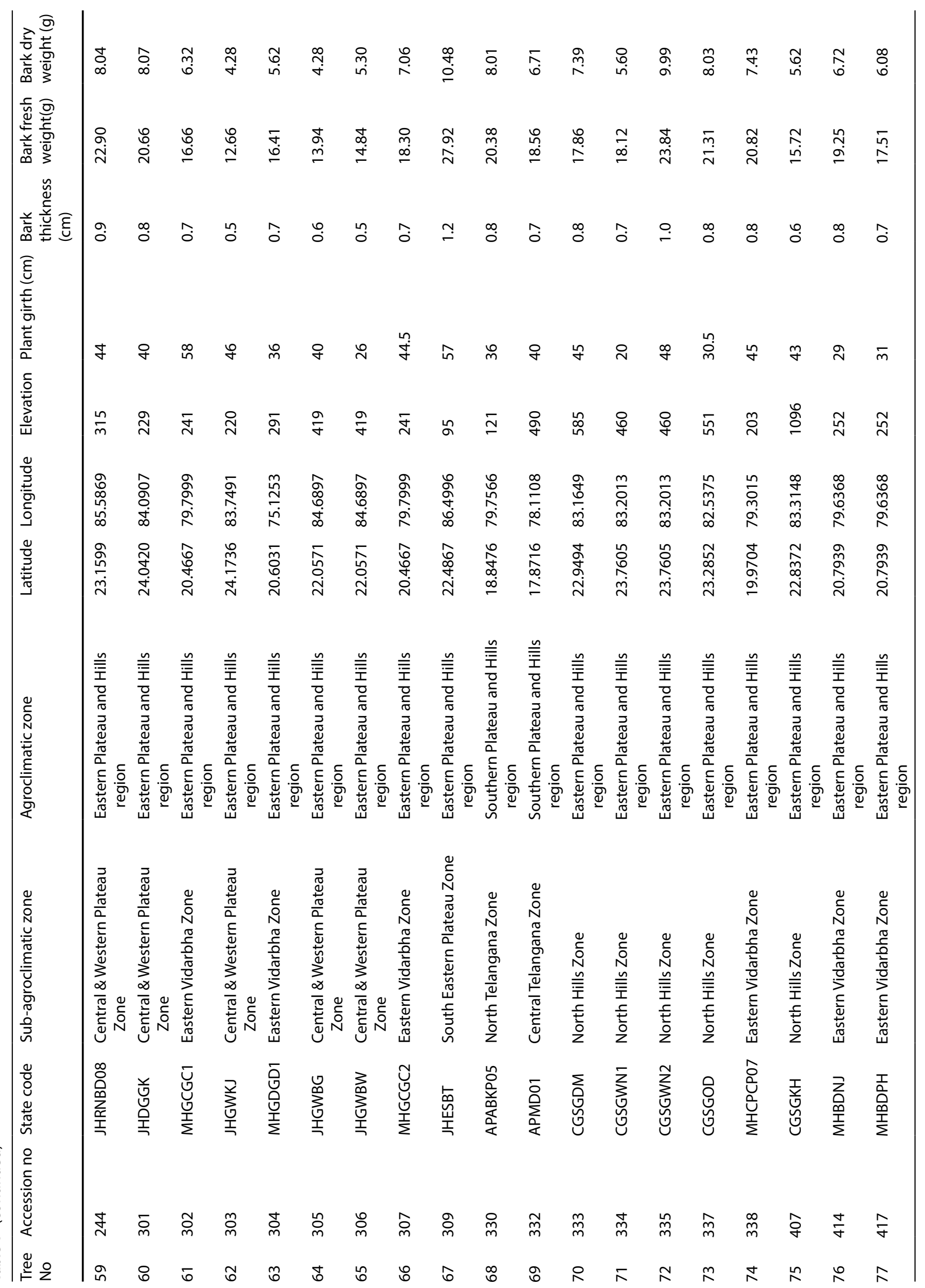




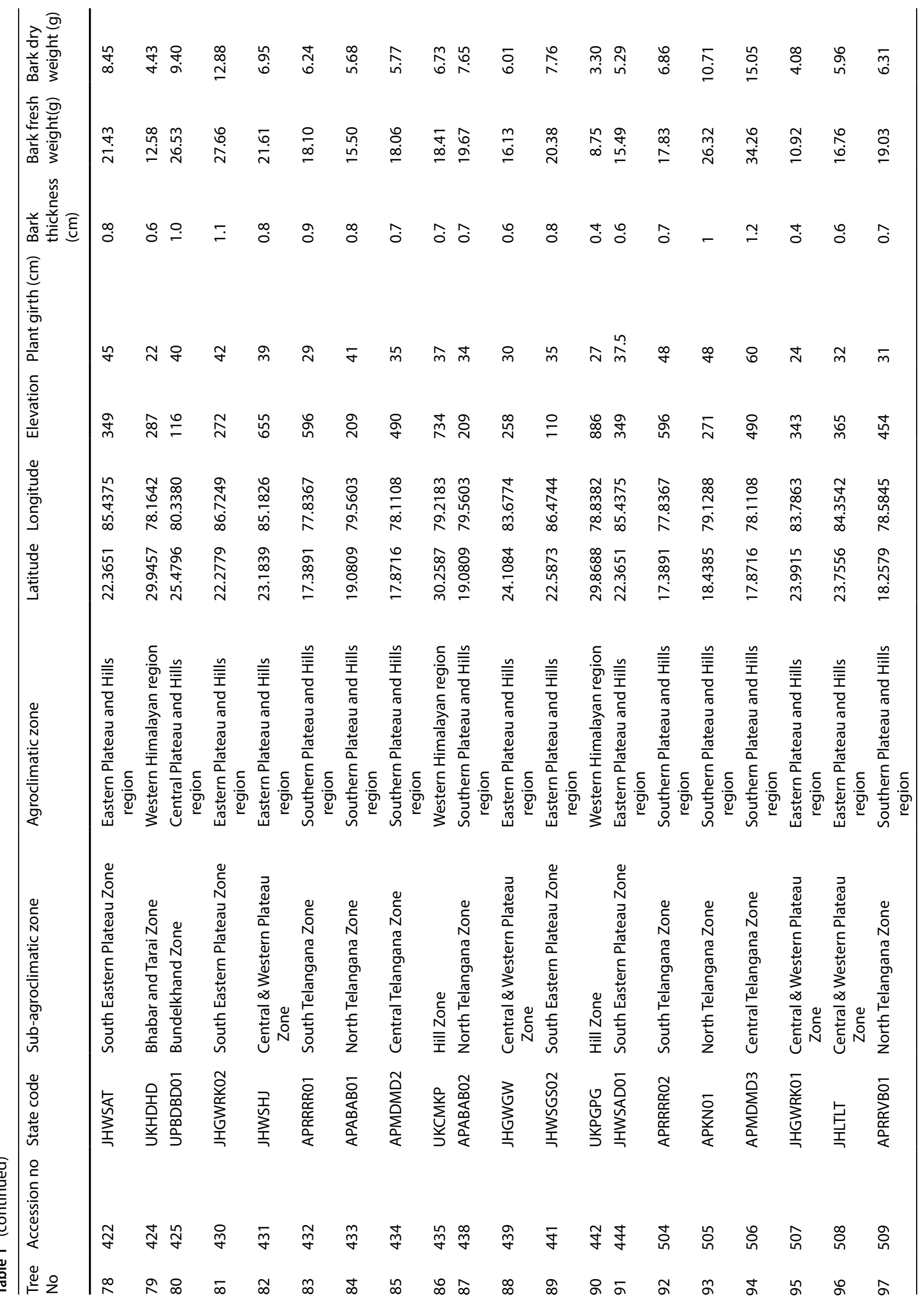




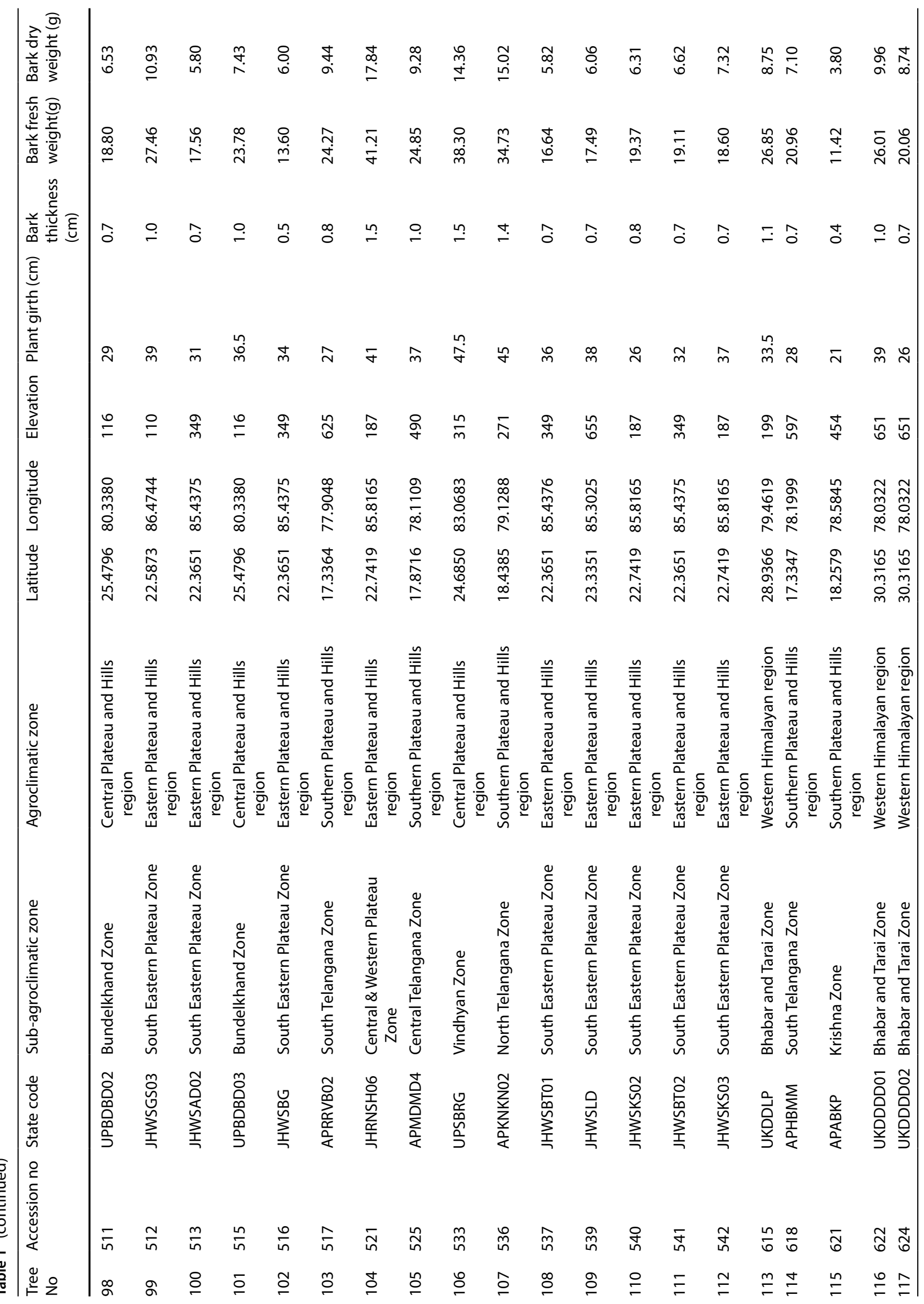




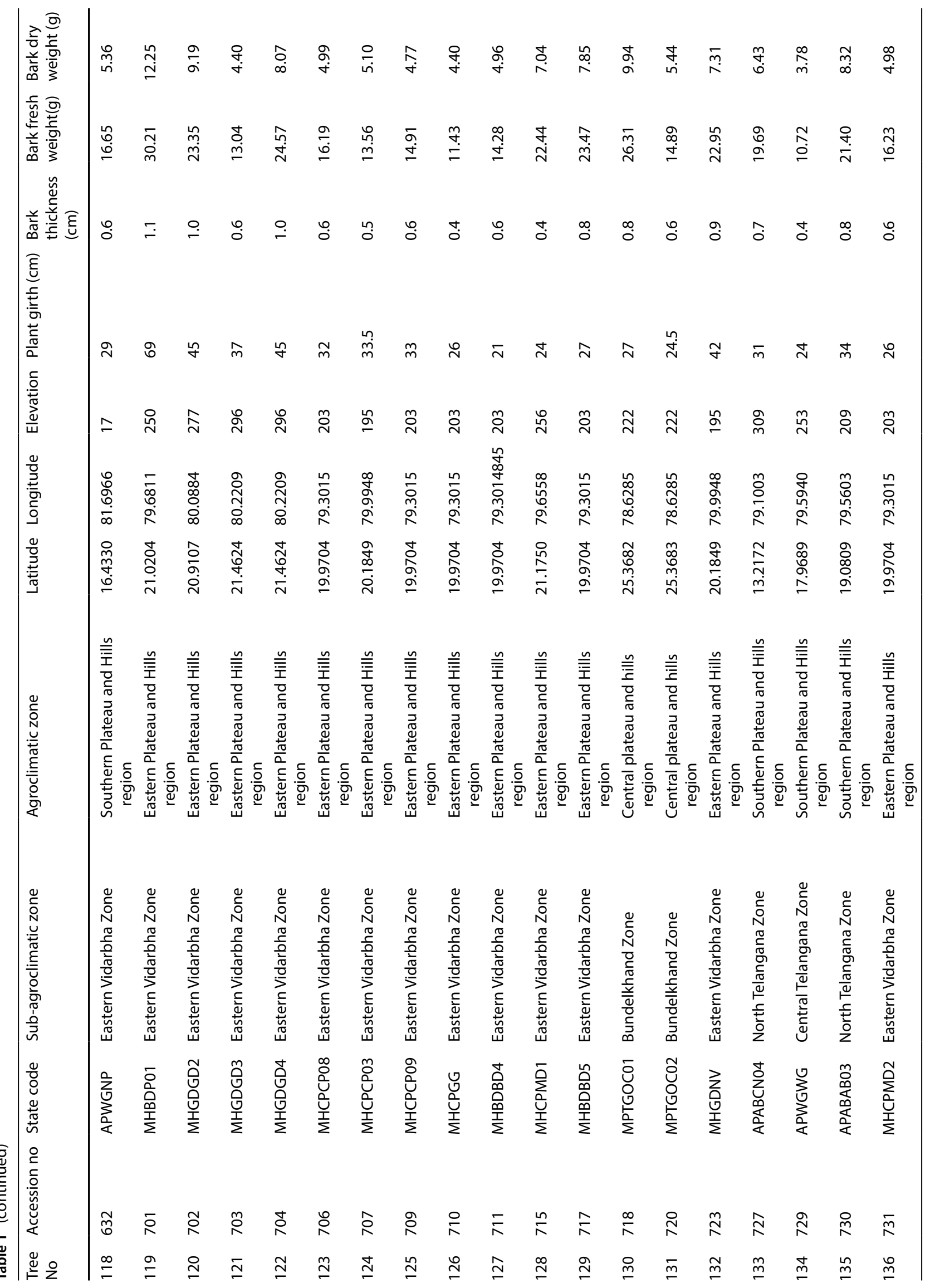




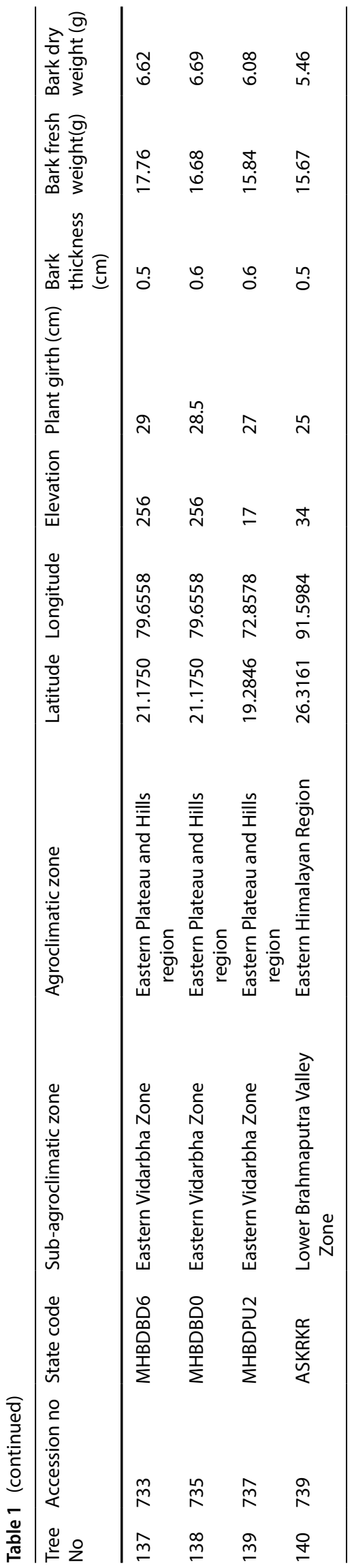

Table 2 Specification of TLC silica gel aluminium plates

\begin{tabular}{ll}
\hline Parameter & Specification \\
\hline Layer thickness & $0.2 \mathrm{~mm}$ \\
$\begin{array}{l}\text { Specific surface area (according to BET; 5-Pt. } \\
\text { measurement) }\end{array}$ & $480-540 \mathrm{~m}^{2} / \mathrm{g}$ \\
Pore volume $\left(\mathrm{N}_{2}\right.$-isotherm) & \\
Laser diffraction & $0.74-0.84 \mathrm{ml} / \mathrm{g}$ \\
Size distribution & $\mathrm{d} 50$ \\
Layer thickness: & $9.5-11.5 \mu \mathrm{m}$, \\
Deviation of layer thickness per plate & $165-235 \mu \mathrm{m}$, \\
Colour test & $\leq 35 \mu \mathrm{m}$, \\
Lipophile & bleu vif organol \\
\hline
\end{tabular}

chamber (TTC), a mobile phase/ developing solvent and derivatization solvent for visualization chromatogram in visual light. The chromatogram of the standard arjunolic acid and sample extracts are subjected to a densitometric scanner for the remission of light proportionate to content concentration in the sample. A software program controls the entire operation. For the purpose, HPTLC system components and software, i.e. CAMAG TLC scanner-3 instrument, equipped with Linomat $\mathrm{V}$ applicator and CATS 3.1 software (CAMAG Chemie-Erzeugnisse \& Adsorptionstechnik AG, Switzerland) were used for estimation of arjunolic acid concentration in the bark samples.

\subsubsection{TLC plate specification and processing}

HTPLC silica gel plates of dimension $20 \mathrm{~cm} \times 10 \mathrm{~cm}(60 \mathrm{~F}$ 254, Merck, India) with specifications given in Table 2 were used. The plates were marked with a pencil for the direction of development and developed with $20 \mathrm{ml}$ methanol per trough in a $20 \times 10 \mathrm{~cm}$ TTC to the upper edge. Subsequently, they were dried in a clean drying oven at $100^{\circ} \mathrm{C}$ for $20 \mathrm{~min}$ and allowed to equilibrate with lab atmosphere (temperature, relative humidity) in a suitable container free from dust and fumes. The heat treatment was given to the plates at $120^{\circ} \mathrm{C}$ for half an hour for activation before the use and held either on both side edges or on the top edge. Most of the time, the plates were used without pretreatment unless chromatography produced impurity fronts due to their contamination.

\subsubsection{Loading standard compound and sample extract on the plate}

An $8 \mu \mathrm{l}$ standard working stock (100 ppm arjunolic acid) or $5 \mu$ l bark extract (equivalent to $1 \mathrm{mg}$ dry bark powder) was loaded on the plates with help of CAMAG Linomat 5 applicator whose parameters are given in Table 3. The samples 
Table 3 CAMAG Linomat 5 applicator specification

\begin{tabular}{ll}
\hline Parameter & Specification \\
\hline Spray gas & Inert gas \\
Sample solvent type & Methanol \\
Dosage speed & $150 \mathrm{nl} / \mathrm{s}$ \\
Pre-dosage volume & $0.2 \mu \mathrm{l}$ \\
Syringe size & $100 \mu \mathrm{l}$ \\
Number of tracks & $6-18$ \\
Application position $Y$ & $8.0 \mathrm{~mm}$ \\
Band length & $7.0 \mathrm{~mm}$ \\
\hline
\end{tabular}

Table 4 Parameter specifications set for HPTLC silica gel aluminium plates for arjunolic acid

\begin{tabular}{ll}
\hline Parameter & Specification \\
\hline Distance from lower edge of plate for TTC & $8 \mathrm{~mm}$ \\
Minimum distance from left and right edge of plate & $10 \mathrm{~mm}$ \\
Minimum space in mm between bands & $4 \mathrm{~mm}$ \\
Band length & $7 \mathrm{~mm}$ \\
\hline
\end{tabular}

were applied as bands by spray-on technique following the scheme given in Table 4.

\subsubsection{Chromatogram development for arjunolic acid}

Plates were developed in a saturated $20 \mathrm{~cm} \times 10 \mathrm{~cm}$ TTC. The chamber was opened and a piece of the filter of size $20 \mathrm{~cm} \times 10 \mathrm{~cm}$ was placed in the rear through. A $20 \mathrm{ml}$ of freshly prepared mobile phase/developing solvent (Composition: $60 \mathrm{ml}$ toluene, $30 \mathrm{ml}$ ethyl acetate, $1 \mathrm{ml}$ formic acid and methanol $10 \mathrm{ml}$ ) was poured into the chamber prepared so that the filter paper thoroughly wetted and adhered to rear TTC wall. Subsequently, the chamber was tilted to the side (about $45^{\circ}$ ) so that the solvent volume in both troughs got equalized. The chamber was placed on the bench and replaced the lid, allowing for $20 \mathrm{~min}$ for its equilibration.

The preferred developing distance $(60 \mathrm{~mm}$ from the lower edge of the plate) with a pencil on the right edge of the plate was marked with the lid having been slide off to the side for the insertion of the plate into the front trough. The plate was adjusted in such a way that its layer faced the filter paper and it's back rested against the front wall of the TTC. The lid was replaced and the plate was developed to the mark. It was followed by the removal of the plate from TTC by opening the lid. The plate was dried vertically in direction of chromatography in a stream of cold air for $5 \mathrm{~min}$. After each development, the residual mobile phase and filter paper were discarded. Before being prepared for the next run, the chamber was dried and, if necessary, also cleaned.

\subsubsection{Derivatization of arjunolic acid in the chromatogram}

The loaded sample on the HPTLC plate was derivatized by immersing for $20 \mathrm{~min}$ in the dip tank device containing $200 \mathrm{ml}$ derivatization solvent reagent (Composition: $85 \mathrm{ml}$ ice-cold methanol, $10 \mathrm{ml}$ acetic acid, $5 \mathrm{ml}$ sulphuric acid and $1 \mathrm{ml}$ anisaldehyde). The plate was subsequently removed from the tank device and allowed the excess reagent to drip off. The back of the plate was wiped off with tissue paper. It was followed by drying of the plate at 100 ${ }^{\circ} \mathrm{C}$ for 2-5 min in the hot air oven.

\subsubsection{Visualization of the developed chromatogram and computation arjunolic acid content in the bark extract}

The derivatized sample fingerprints (chromatograms), along with standard arjunolic acid chromatogram of a known quantity, obtained by derivatization was scanned at $595 \mathrm{~nm}$ on CAMAG scanner (visual; Fig. 2) with the specification given in Table 5. A software program supported the scanner for start/endpoint for scanning plates, baseline correction, resolution and coverage peak area, whose specification is mentioned in Table 6. The optical density of the sample bands was compared with that of the standard band developed from loading known quantity of pure arjunolic acid for computation of arjunolic acid content in the corresponding bark samples (Figs. 3, 4, 5, 6). Let the peak area for bark sample be " $\mathrm{x}$ " and for pure arjunolic acid be " $y$ ". The arjunolic acid content in bark sample (B) be computed from the following expression:

$B(\mu \mathrm{g} / \mathrm{mg}$ bark dry weight $)=0.8 \mathrm{x} / \mathrm{y}$

\section{Results}

\subsection{Arjunolic acid content}

Arjunolic acid in the bark samples collected from one hundred and forty Terminalia arjuna accessions, belonging to nine states and five agro-climatic zones, assembled as germplasm bank was estimated. The arjunolic acid content was expressed as a percentage. The highest percentage of arjunolic acid in the extracts was found to be $0.54 \%$ in accession UKDDLP and the lowest percent extractive value $0.003 \%$ was estimated in the accession APMD03, methanol fraction of Terminalia arjuna stem 


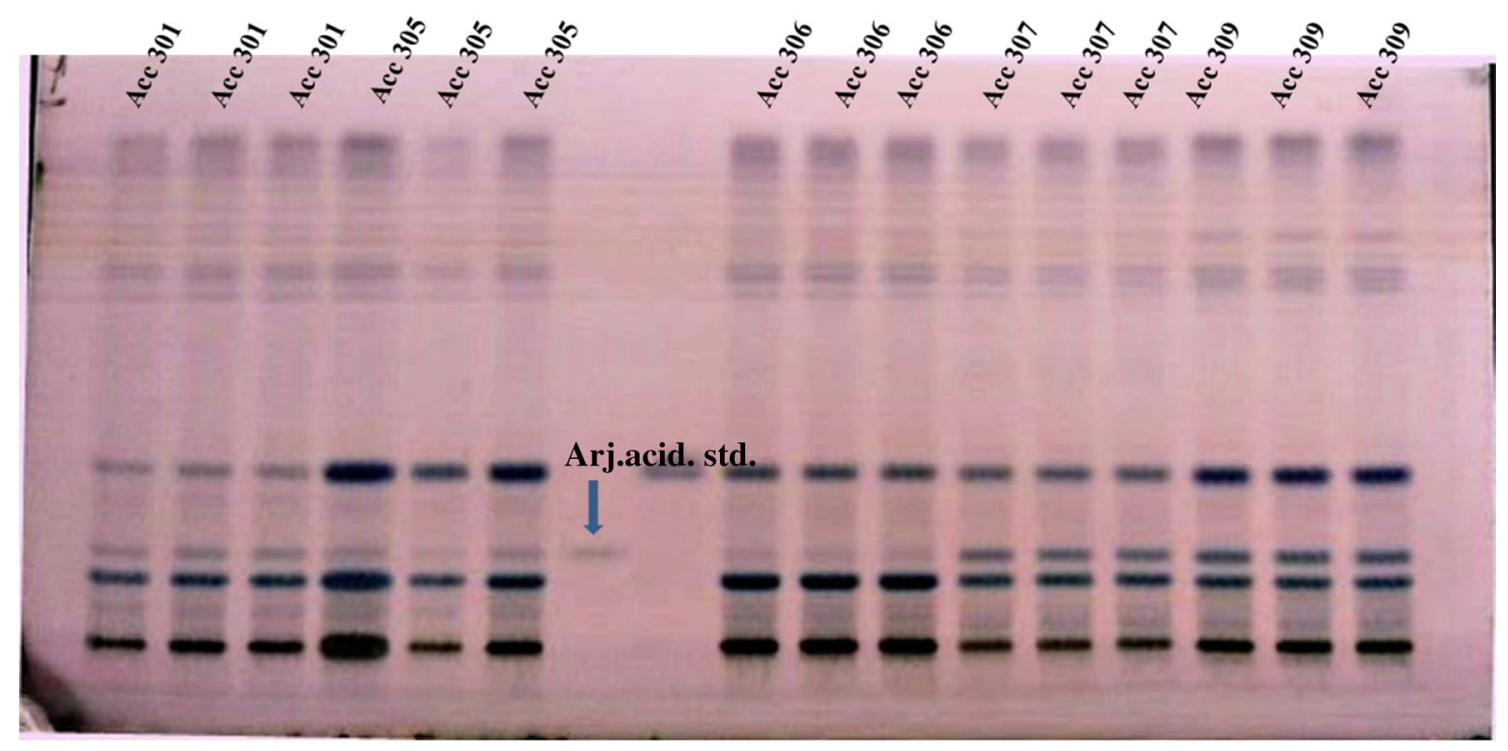

Fig. 2 TLC profile of ethyl acetate stem bark extract in UV light

Table 5 Specification of densiometric scanner (visible)

\begin{tabular}{ll}
\hline Parameter & Specification \\
\hline Wavelength & $595 \mathrm{~nm}$ \\
Lamp & W (Tungsten) \\
Measurement type & Remission \\
Measurement mode & Absorption \\
Optical filter & Second order \\
Detector mode & Automatic \\
PM high voltage & $256 \mathrm{~V}$ \\
\hline
\end{tabular}

Table 6 Software setting specifications used for capturing analytical data of arjunolic acid

\begin{tabular}{ll}
\hline Parameter & Specification \\
\hline Data filtering & Savitsky-Golay 7 \\
Baseline correction & Lowest Slope \\
Peak threshold min. slope & 5 \\
Peak threshold min. height & $10 \mathrm{AU}$ \\
Peak threshold min. area & 50 \\
Peak threshold max. height & $990 \mathrm{AU}$ \\
Track start position & $5.0 \mathrm{~mm}$ \\
Track end position & $90.0 \mathrm{~mm}$ \\
Display scaling & Automatic \\
\hline
\end{tabular}

bark was used. The percentage of arjunolic acid in the extracts was ranging from $0.003 \%$ to $0.54 \%$. The percentage of arjunolic acid the stem bark of arjun is given in Table No.7.

\subsection{Arjunolic acid (\%)}

Arjunolic acid (\%) was significantly $(p<0.05)$ affected by state and T. arjuna accessions. The agro-climatic zone did not influence arjunolic acid (\%). Accessions from the Uttrakhand (UK) state exhibited significantly the highest value for arjunolic acid. On the other hand, the accessions from Assam (AS) state had significantly the lowest value for arjunolic acid (\%). The accessions from UK state registered 238\% higher value for arjunolic acid content than accessions from AS state (Fig. 7l).

Agroclimatic zones significantly $(p<0.05)$ influenced arjunolic acid (\%). Agro-climatic zone WHR had the significantly highest for arjunolic acid (\%). In contrast, agro-climatic zone EHR recorded the significantly lowest value for arjunolic acid (\%). The accessions belonging WHR had 238\% higher value for arjunolic acid (\%) than those belonging to EHR (Fig. 7 II).

The sampled accessions exhibited significant $(p<0.05)$ variation in the arjunolic acid (\%) in their barks. Accession UKDDLP belonging to Uttrakhand state and WHR agroclimatic zone registered the highest value and accession APMD03 belonging to Andhra Pradesh and SPH agro-climatic zone, the lowest value for the arjunolic acid (\%). The arjunolic acid increment was 17,900\% in accession UKDDLP over accession APMD03 (Table 7).

\section{Discussion}

A species survives through various populations, which become discrete in space and time due to the combined influence of intrinsic genetical changes and extrinsic 


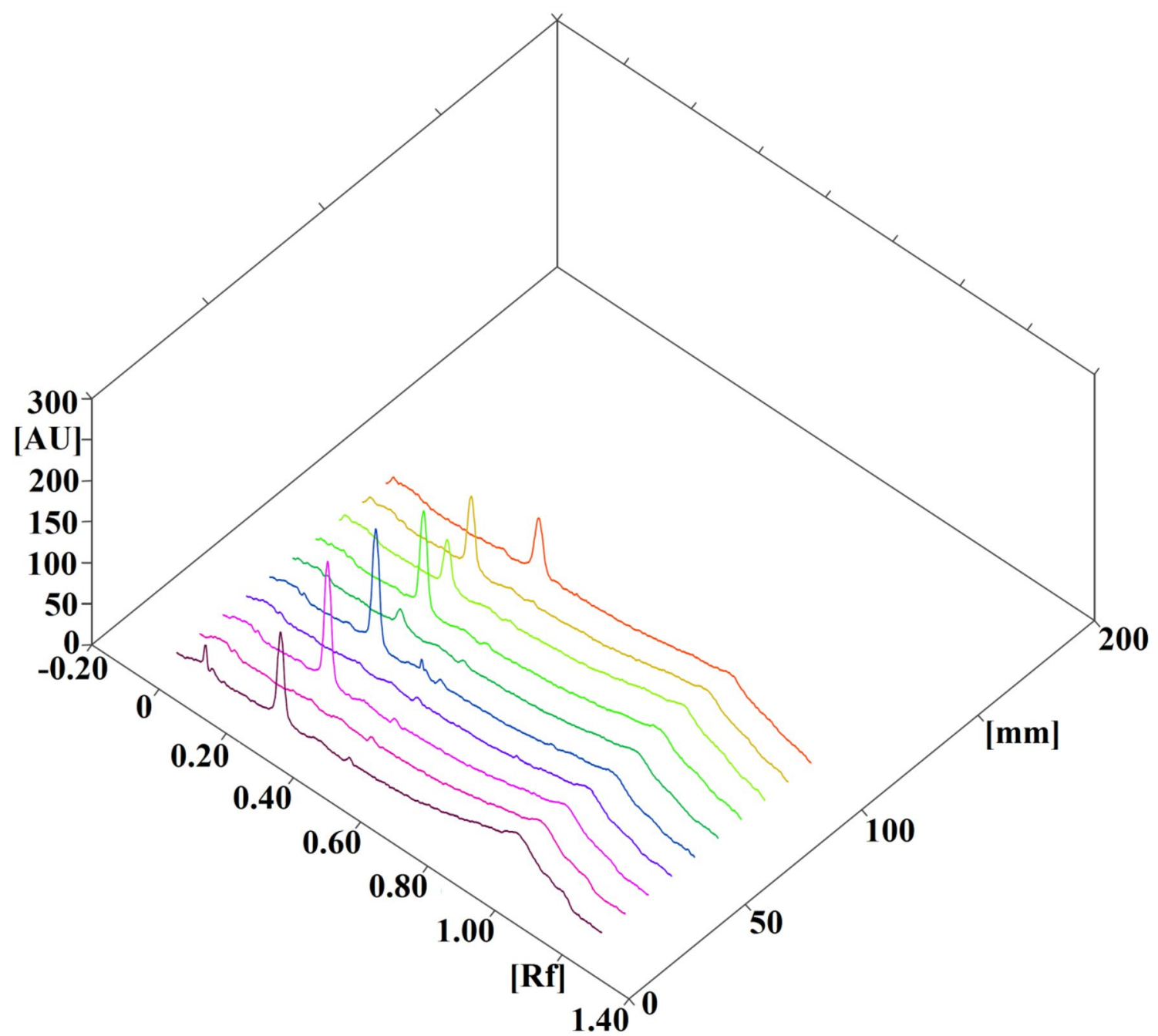

Fig. 3 Photochromatogram of the HPTLC plate of arjunolic acid standard illustrated by TLC scanner 3(CAMAG) in which the $X$-axis represents $\mathrm{RF}$ of each detected spot, $Y$-axis the height of the peaks (Spot's density), and Z-axis location on the plate, respectively at $595 \mathrm{~nm}$

Fig. 4 HPTLC graph of arjunolic acid standard illustrated by TLC scanner 3(CAMAG) in which the $X$-axis represents the height of the peaks and $Y$-axis. $\mathrm{RF}$ of each detected spot respectively at $595 \mathrm{~nm}$

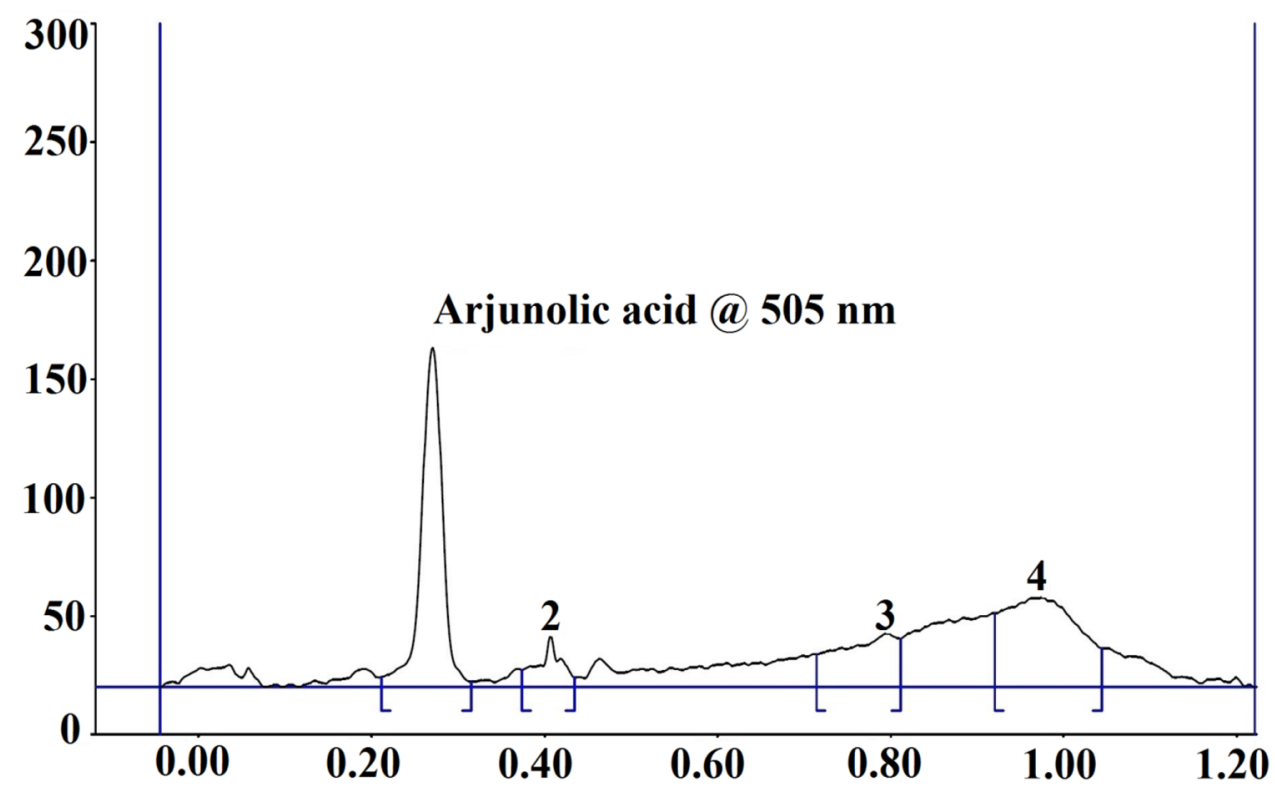




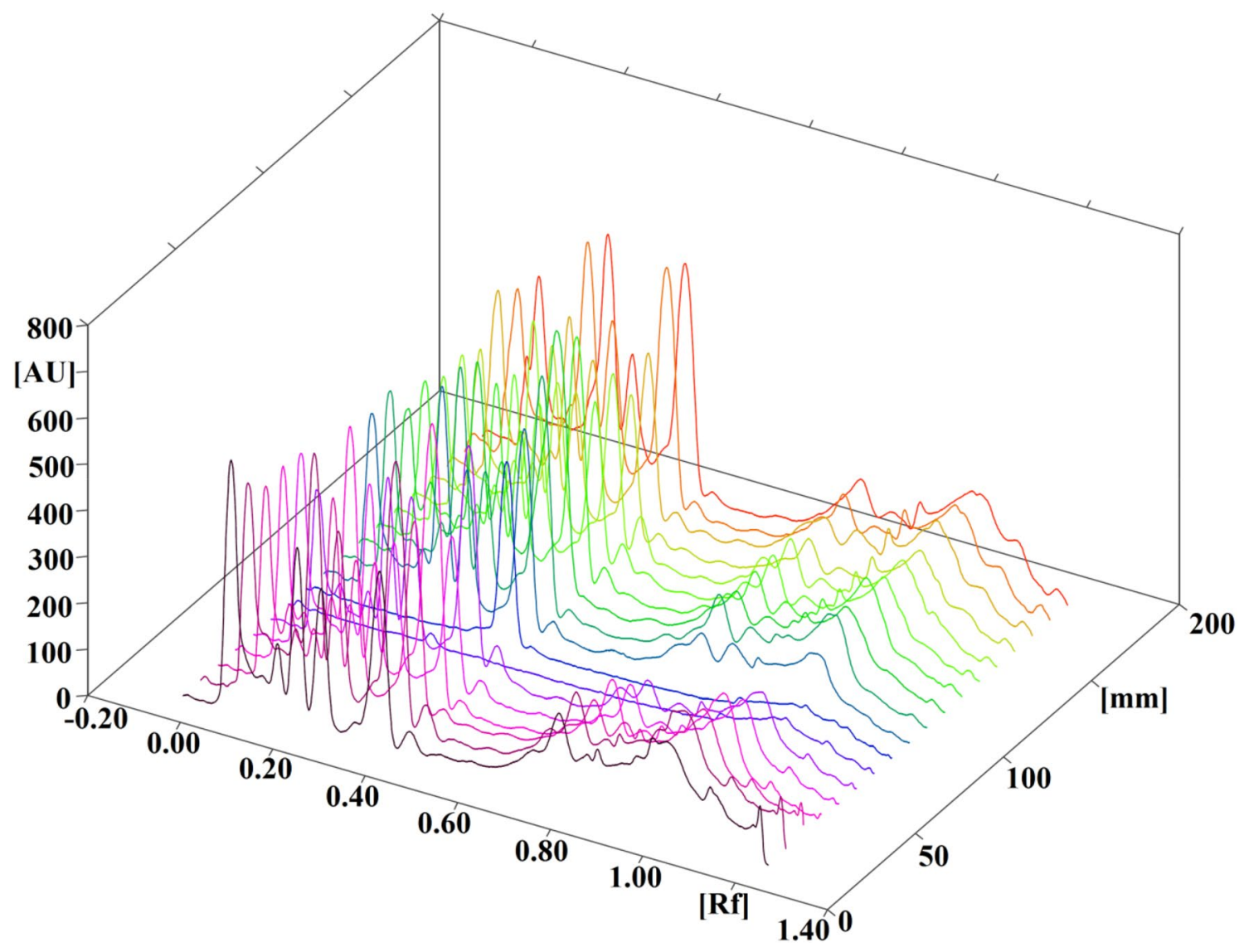

Fig. 5 Photochromatogram of the HPTLC plate of arjun bark extract (Sample 45) illustrated by TLC scanner 3(CAMAG) in which the $X$-axis represents RF of each detected spot, $Y$-axis the height of the peaks (Spot's density), and Z-axis location on the plate, respectively at $595 \mathrm{~nm}$

Fig. 6 HPTLC graph of arjun bark extract (Sample 45) sample represented by TLC scanner 3(CAMAG) in which the $X$ and $Y$-axis represents the height of the peaks and RF of each detected spot respectively at $595 \mathrm{~nm}$

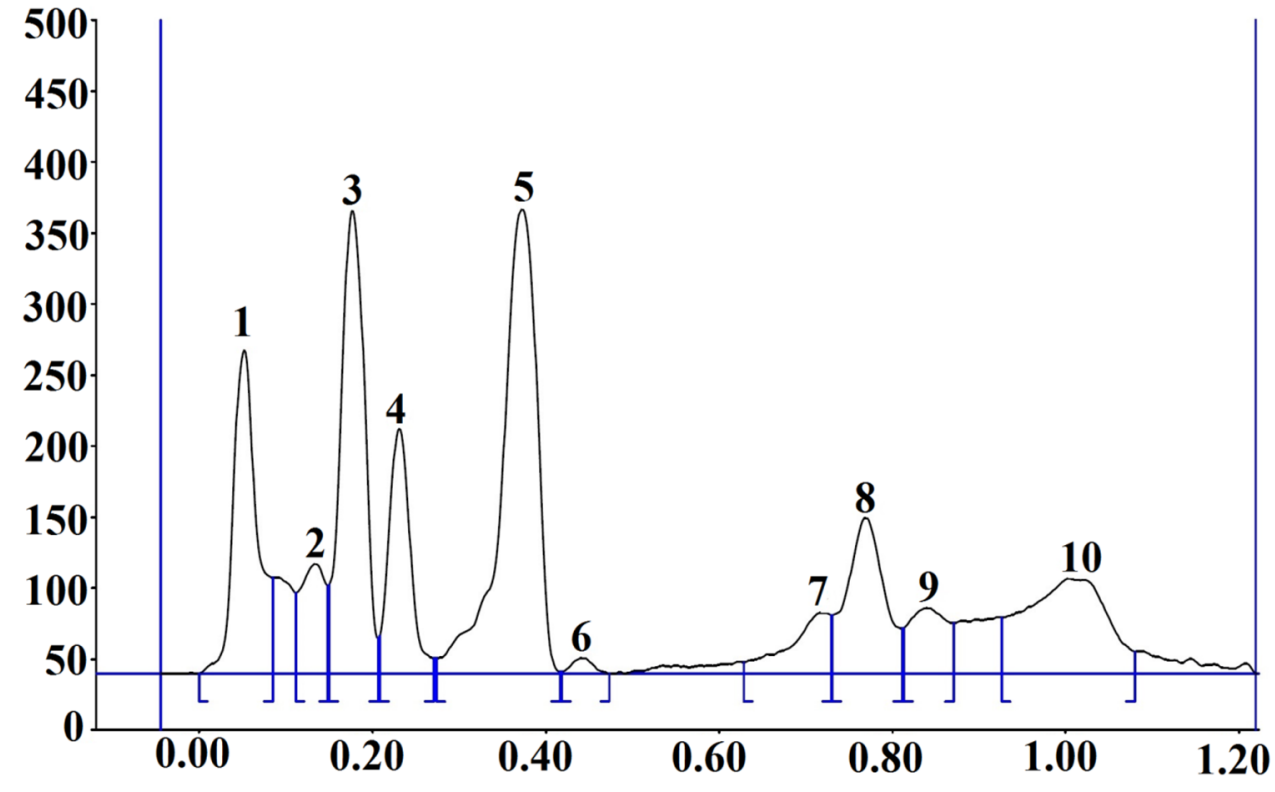




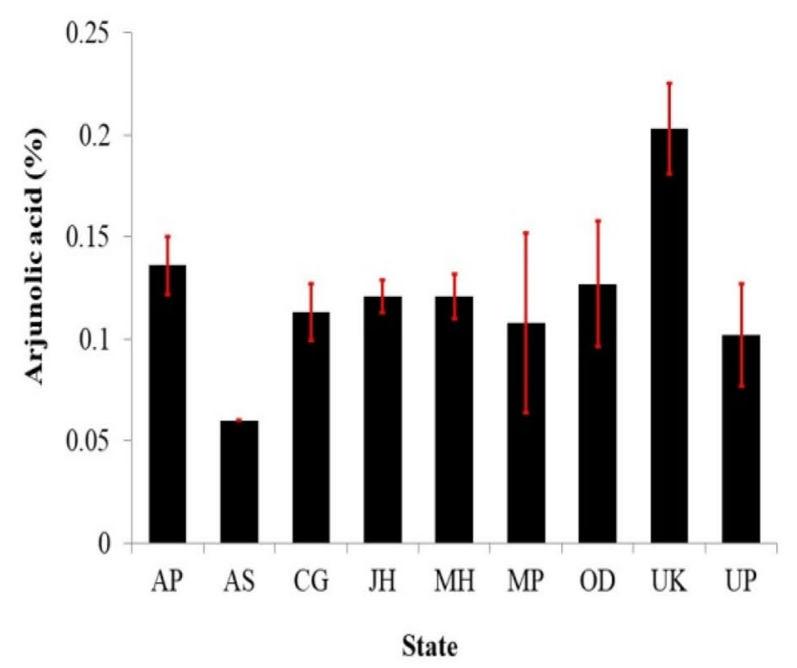

(I)

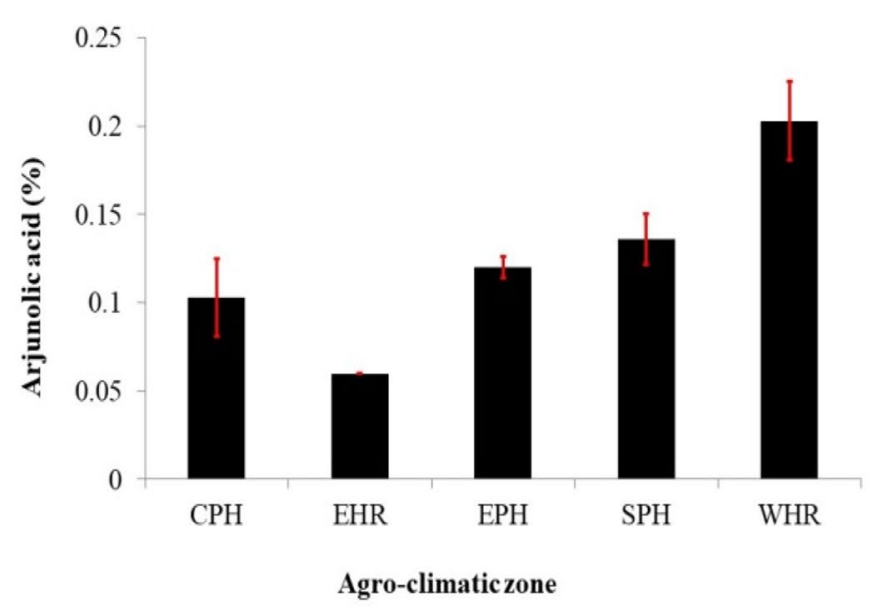

(II)
Fig. 7 I=Arjunolic acid content (\%) in the bark samples obtained from accessions of nine states. II=Arjunolic acid content (\%) in the bark samples obtained from accessions of five agro-climatic zones.

geo-climatic selection forces. The intrinsic genetical changes are perpetually brought by sexual recombination, mutations, migrations, inbreeding, admixing, etc. and generate variability and differentiation. The extrinsic geo-climatic selection forces are in fact drivers for adaptation and conservation of specific genetic pattern (s) of the population. Therefore, the dataset for populations needs to be analyzed taking these considerations.

In most of the traditional systems of treatment, the different parts of the plants used in the treatments for different ailments by the local peoples of those particular area. Plants synthesize metabolites during their biosynthetic pathways, these metabolites used by the plants called primary metabolites. Further, plants produce secondary metabolites mostly in stress conditions and used them for defensive purposes. These secondary metabolites accumulate in specialized vesicles or organs in the plant body. Phenolic compounds, alkaloids, terpenoids, volatile oils are some example of secondary metabolites. These secondary metabolites used in different purposes in the treatments of different diseases and disorders [13]. Consequently, the globe Health Organization (WHO) established a definition of medicinal plants: "A medicinal plant is any plant or plant part that can be used for the therapeutic purpose or that may be a precursor for the synthesis of helpful drugs" [14]. Moreover, the United Nations agency (World Health Organization, Geneva.2000) defines the medicinal plant as seasoning preparations made by subjecting plant materials to extraction, fractionation, purification, concentration
Vertical lines represent the standard deviation (SD). Data are mean of three replicates and significant at $p<0.05$

or different physical or biological processes that can be made for immediate consumption or as a basis for seasoning merchandise. Medicinal plants are those plants that contain active ingredients used to cure the disease [15].

A large number of secondary metabolites produced by the plants that do not directly involve in primary processes such as growth and development. Secondary metabolites comprise three chemically distinct groups, i.e. terpene phenolic compounds and $\mathrm{N}$-containing compounds (strychnine, nicotine, caffeine, cocaine, capsaicin). For many years, they have been presumed to be by-products or metabolic wastes and do not participate in physiological functions. They have now been recognized to perform plant defense functions and involve in signal transduction, playing a major role as the deterrent to adverse conditions and microbial/ pest attacks. For example, high tannin content in sorghum cultivars conferring astringency and poor digestibility discourage attack by birds [16]. High salicylic acid content confers adaptability and pathogen resistivity to plants [17-20].

Arjunolic acid along with other secondary metabolites like phenols and tannins accumulates in the bark and possibly confer resistance against natural vagaries and insect pest attacks. Interestingly, the compound has been extensively investigated for pharmaceutical purposes rather than its biological functions in the host plant, i.e. $T$. arjuna. Arjunolic acid has also been reported from other plants such as Cochlospermum tinctorium, Cornus capitata, Leandra chaetodon, Combretum leprosum, Campsis grandiflora, Syzygium guineense, Combretum nelsonii [21]. Like 
Table 7 Arjunolic acid (\%) in the bark of 140 accessions of Terminalia arjuna. Data are means of three replicates and significant at $p<0.05$

\begin{tabular}{|c|c|c|c|c|c|c|c|}
\hline Accessions & $\%$ & Accessions & $\%$ & Accessions & $\%$ & Accessions & $\%$ \\
\hline APAB01 & 0.17 & CGSGWN02 & 0.04 & JHRNSL02 & 0.01 & МНСРСР06 & 0.07 \\
\hline АРAB02 & 0.12 & CGSGWN03 & 0.12 & JHRNSL03 & 0.06 & МНСРСР07 & 0.06 \\
\hline АРАВ03 & 0.22 & CGSJ04 & 0.10 & JHRNSL04 & 0.04 & МНСРСР08 & 0.03 \\
\hline AРAB04 & 0.18 & CGSJOD & 0.05 & JHRNSL05 & 0.07 & МНСРСР09 & 0.09 \\
\hline APAB05 & 0.21 & JHDGGK & 0.30 & JHWSAD01 & 0.12 & MHCPGG & 0.30 \\
\hline APABCN & 0.12 & JHESBT & 0.12 & JHWSAD02 & 0.11 & MHCPMD01 & 0.06 \\
\hline APHBMM & 0.22 & JHGWBG & 0.15 & JHWSAT & 0.06 & MHCPMD02 & 0.19 \\
\hline APKN01 & 0.04 & JHGWBW & 0.10 & JHWSBG & 0.27 & MHCPMD03 & 0.20 \\
\hline APKN02 & 0.13 & JHGWGW & 0.34 & JHWSBT01 & 0.11 & MHGCGC01 & 0.17 \\
\hline APMD01 & 0.06 & JHGWKJ & 0.17 & JHWSBT02 & 0.01 & MHGCGCO2 & 0.09 \\
\hline APMD02 & 0.08 & JHGWRK01 & 0.14 & JHWSGS01 & 0.03 & MHGDGD01 & 0.13 \\
\hline APMD03 & 0.00 & JHLTLT & 0.20 & JHWSGS02 & 0.07 & MHGDGD02 & 0.04 \\
\hline APMD04 & 0.09 & JHRNBD01 & 0.07 & JHWSGS03 & 0.09 & MHGDGD03 & 0.05 \\
\hline APRR01 & 0.22 & JHRNBD02 & 0.25 & JHWSHJ & 0.01 & MHGDGD04 & 0.04 \\
\hline APRR02 & 0.14 & JHRNBD03 & 0.28 & JHWSKS01 & 0.07 & MHGDNV & 0.04 \\
\hline APRRVB01 & 0.22 & JHRNBD04 & 0.07 & JHWSKSO2 & 0.04 & MPTGOC01 & 0.19 \\
\hline APRRVB02 & 0.09 & JHRNBD05 & 0.36 & JHWSLD & 0.29 & MPTGOC02 & 0.03 \\
\hline APWGNP & 0.17 & JHRNBD06 & 0.13 & MHBDAL & 0.08 & ODMBBP & 0.32 \\
\hline APWGWG & 0.09 & JHRNBD07 & 0.03 & MHBDBD01 & 0.07 & ODSGBK & 0.03 \\
\hline ASKRKR & 0.06 & JHRNBD08 & 0.03 & MHBDBD02 & 0.23 & ODSGSG01 & 0.07 \\
\hline CGBT01 & 0.05 & JHRNRN01 & 0.22 & MHBDBD03 & 0.07 & ODSGSG02 & 0.09 \\
\hline CGBT02 & 0.08 & JHRNRN02 & 0.07 & MHBDBD04 & 0.15 & UKCMKP & 0.14 \\
\hline CGBTAP & 0.39 & JHRNRN03 & 0.11 & MHBDBD05 & 0.05 & UKDDDD01 & 0.07 \\
\hline CGDT01 & 0.11 & JHRNRN04 & 0.18 & MHBDBD06 & 0.08 & UKDDDD02 & 0.09 \\
\hline CGDT02 & 0.29 & JHRNRN05 & 0.07 & MHBDBD07 & 0.04 & UKDDLP & 0.54 \\
\hline CGDT03 & 0.18 & JHRNRN06 & 0.11 & MHBDBD08 & 0.08 & UKHDHD & 0.32 \\
\hline CGDT04 & 0.09 & JHRNRN07 & 0.13 & MHBDGV & 0.09 & UKNTHD & 0.04 \\
\hline CGDT05 & 0.06 & JHRNRN08 & 0.02 & MHBDNJ & 0.43 & UKPGPG & 0.20 \\
\hline CGDTSG & 0.08 & JHRNSH01 & 0.36 & MHBDPH & 0.21 & UKUSTD & 0.22 \\
\hline CGSGBN & 0.17 & JHRNSHO2 & 0.20 & MHBDPU01 & 0.03 & UPBDBD01 & 0.08 \\
\hline CGSGDM & 0.07 & JHRNSHO3 & 0.07 & MHBDPU02 & 0.15 & UPBDBD02 & 0.23 \\
\hline CGSGKH & 0.02 & JHRNSHO4 & 0.20 & МНСРСР01 & 0.41 & UPBDBD03 & 0.09 \\
\hline CGSGMP & 0.03 & JHRNSH05 & 0.13 & МHСРСР02 & 0.09 & UPJNJN01 & 0.11 \\
\hline CGSGSG & 0.05 & JHRNSH06 & 0.09 & МНСРСР03 & 0.08 & UPJNJN02 & 0.05 \\
\hline CGSGWN01 & 0.06 & JHRNSL01 & 0.06 & МHСРСР05 & 0.17 & UPSBRG & 0.05 \\
\hline
\end{tabular}

morphometric traits, arjunolic acid content in the bark also exhibits a great variation across accessions, locations and agro-climatic zones. Chemically, arjunolic acid is triterpenoid saponins of great therapeutic value but its biosynthesis pathways are obscure. Consequently, the observed variability of its content across accessions, locations and agro-climatic regions may be attributed to the interaction between genotype and geo-climatic condition. In consonant, accession UKDDLP from Uttrakhand and Western Himalayan agro-climatic region produces the highest amount of arjunolic acid and accession APMD03 from Andhra Pradesh of Southern plateau \& Hill agro-climatic region, the lowest amount of arjunolic acid. The plausible reason appears to be the temperate region and high annual rainfall of $1500 \mathrm{~mm}$ in Uttrakhand in comparison to arid condition with $50-100 \mathrm{~mm}$ average annual rainfall in Andhra Pradesh. The present study endorses that geoclimatic variables like environment, habitats, geographical conditions, altitude etc. have reflective and reproducible effects on the quantitative content of arjunolic acid in $T$. arjuna.

In the literature, the investigations have been devoted to the extraction and purification of arjunolic acid from the bark of T. arjuna employing HPLC or HPTLC systems [22]. In the present investigation, the HPTLC procedure has been adopted for quantification of arjunolic acid in the bark of 140 accessions of T. arjuna that has indeed been done for the first time on such a large scale. Our 
results bring out a great opportunity for field selection of superior accessions of $T$. arjuna for obtaining the high yield of arjunolic acid. The accessions belongs to the Uttrakhand state UKDDLP in India and were found to be with the highest content of arjunolic acid in their stem bark when compared to accessions of Andhra Pradesh. These accession may be introduced for large-scale plantation for commercial extraction of arjunolic acid on a sustainable basis.

\section{Conclusions}

Terminalia arjuna is a plant with various pharmacological activities. Different parts of the plant is used for different activities. The most widely used part of the plant is the stem bark. The present study was aimed to investigate the phytochemical screening with the help of HPTLC that revealed the presence of high arjunolic acid content in different accessions of Terminallia arjuna bark extract from Uttrakhand in India. Thus in conclusion:

- The accessions from the Uttrakhand state and Western Himalayan region agro-climatic zone were found with the high content of arjunolic acid.

- This triterpenoid saponin i.e., arjunolic acid has been reported for the treatment of cardiovascular disorders as well as some other diseases.

- However, further studies are required to separate the compound of interest in purified form from the partially purified plant extracts for the preparation of medicines. Pharma industries have a big demand for arjun bark as it used in different pharmaceutical formulations.

- The identified accessions with high arjunolic acid content in the bark need to be incorporated in the genetically improved clones and introduced to the commercial plantation for high return and conservation of natural resources of T. arjuna."

Acknowledgments I acknowledge with thanks, Director of Tropical Forest Research Institute, Jabalpur, to provide me necessary facilities during the present work. I am also thankful to Dr. S. A. Ansari and Dr. Neelu Singh, Tropical Forest Research Institute for their support and guidance during the work.

\section{Compliance with ethical standards}

Conflict of interest The author(s) declare that they have no competing interests.

Open Access This article is licensed under a Creative Commons Attribution 4.0 International License, which permits use, sharing, adaptation, distribution and reproduction in any medium or format, as long as you give appropriate credit to the original author(s) and the source, provide a link to the Creative Commons licence, and indicate if changes were made. The images or other third party material in this article are included in the article's Creative Commons licence, unless indicated otherwise in a credit line to the material. If material is not included in the article's Creative Commons licence and your intended use is not permitted by statutory regulation or exceeds the permitted use, you will need to obtain permission directly from the copyright holder. To view a copy of this licence, visit http://creativecommons .org/licenses/by/4.0/.

\section{References}

1. Ncube NS, Afolayan AJ, Okoh Al (2008) Assessment techniques of antimicrobial properties of natural compounds of plant origin: current methods and future trends. African J Biotech 7(12):1797-1806

2. Chomvhalow N (2000) Production of medicinal and aromatic plants in Southeast Asia. AUJ Tech 4:84-89

3. Tripathi VK, Singh B (1996) Terminalia arjuna -its present status (a review). Orient J Chem 12:1-16

4. Pettit GR, Hoard MS, Doubek DL, Schmidt JM, Petrit RK (1996) Antineoplastic agents 338- the cancer cell growth inhibitory constituents of Terminalia arjuna. J Ethnopharmacol 53:57-63

5. Rose J, Treadway S (2000) Herbal support for a healthy cardiovascular system. Clin Nutr Insights 6:16

6. Khan S, Balick MJ (2001) Therapeutic plants of ayurveda: a review of selected clinical and other studies for 166 species. J Altern Compliment Med 7:405-515

7. Dwivedi S (2007) Terminalia arjuna Wight \& Arn.-a useful drug for cardiovascular disorders. J Ethnopharmacol 114(2):114-129

8. Rao Linga M, Savithramma N, Suhrulatha D (2011) Screening of medicinal plants for secondary metabolites. Middle-East J Sci Res 8(3):579-584

9. Pullaiah T (2006) Encyclopedia of world medicinal plants. Regency Publication, New Delhi, pp 1-525

10. Kamboj VP (2007) Herbal medicine. Curr Sci 3:343-350

11. Patwardhan B, Vaidhya ADB, Chorghade M (2004) Ayurveda and natural products drug discovery. Curr Sci 86:789-799

12. Satyavati GV, Gupta AK, Tandon N (1987) Medicinal plants of India. Indian Council of Medical Research, New Delhi, India

13. Ghani A (2003) Medicinal plants of bangladesh, 2nd edn, pp 1-2, $55-57,402$, and 500

14. Goldstein A, Aronow L, Kalman SM (1974) Principles of drug action: the basis of pharmacology. Wiley, New York

15. Okigbo RN, Anuagasi CL, Amadi JE, Ukpabi UJ (2009) Potential inhibitory effects of some African tuberous plant extracts on Escherichia coli, Staphylococcus aureus and Candida albicans. Int J Int Bio 6(2):91-99 
16. Butler LG, RiedI DJ, Lebryk DG, Blytt HJ (1984) Interaction of proteins with sorghum tannin: mechanism, specificity and significance. J Am Oil Chem Soc 61(5):916-920

17. Malamy J, Carr JP, Klessig DF, Raskin I (1990) Salicylic acid: a likely endogenous signal in the resistance response of tobacco to viral infection. Science 250:1002-1004

18. Metraux JP, Signer H, Ryals J, Ward E, Wyss-Benz M, Gaudin J, Raschdorf K, Schmid E, Blum W, Inverardi B (1990) Increase in salicylic acid at the onset of systemic acquired resistance in cucumber. Science 16:250(4983), 1004-1006

19. Rasmussen JB, Hammerschmidt R, Zook MN (1991) Systemic induction of salicylic acid accumulation in cucumber after inoculation with Pseudomonas Syringae Pv Syringae. Plant Physio 97(4):1342-1347

20. Ward ER, Uknes SJ, Williams SC, Dincher SS, Wiederhold DL, Alexander DC, Ahl-Goy P, MBtraux JP, Ryals JA (1991) Coordinate gene activity in response to agents that induce systemic acquired resistance. Plant Cell 3:1085-1094

21. Hemlatha T, Pulavendran S, Balachandran C, Murali Manohar B, Puvanakrishnan R (2010) Arjunolic acid: a novel phytomedicine with multifunctional therapeutic applications. Ind J Exp boil 48:238-247

22. Verma SC, Jain CL, Padhi MM, Devalla RB (2012) Microwave extraction and rapid isolation of arjunic acid from Terminalia arjuna (Roxb. ex DC.) stem bark and quantification of arjunic acid and arjunolic acid using HPLC-PDA technique. J Sep Sci 35:1627

Publisher's Note Springer Nature remains neutral with regard to jurisdictional claims in published maps and institutional affiliations. 